\title{
FINANCIAL AND LEGAL ASPECTS OF POWER DECENTRALIZATION REFORM
}

\section{Sudarenko O. V.}

\section{INTRODUCTION}

Ideas of human-centrism around the world provide for the necessity of reforms in the field of state and regional policy. One of these reforms is the reform concerning power decentralization. Power bodies both central and local are introducing more and more elements of interactive and participatory administration in their activities, in which citizens are involved in public administration at the early stages of decision-making ${ }^{1}$. Reforms require funds and their distribution among public funds. The global experience of power decentralization reforms shows that the outcomes of such reforms can be observed only after a long time after their introduction. So, studying international practices of financial and legal aspects of decentralization and its implementation in Ukraine, which started its reform only in 2015 , is a vital issue.

The issues of power decentralization are the subject of scientific research of legal and economic science, and management theory representatives, namely: T.M. Baranovska, N.V. Vorotina, B.M. Danylyshyn, I.B. Zaverukha, A.U. Nashymets-Naumova, M.O. Petryshyna, O.O. Petryshyn, V.V. Pylypiv, N.U. Pryshva, A.F. Tkachiuk, S.M. Seryogina, O.D. Chepel at al.

The article is aimed at studying financial and legal aspects of power decentralization reforms both in countries worldwide and in Ukraine, studying the international experience of such reform introduction and implementation it into Ukrainian practice, the development of proposals concerning legislation improvement in the field mentioned.

\section{Financial and Legal Aspects of Power Decentralization: International Experience}

The legal basis for decentralization, in addition to national legislation, includes the Worldwide Declaration of Local Self-Government, adopted on September 26, 1985 in Rio de Janeiro by the World Alliance of Local SelfGovernment at the XXVII International Congress and the European Charter of

\footnotetext{
${ }^{1}$ Барановська Т.М. Державна політика розвитку територіальних громад в Україні: дис. ... канд. наук 3 державного управління. Харків, 2016. С. 92.
} 
Local Self-Government as of $15.10 .1985^{2}$. Every state makes choice independently based on principles stipulated by these documents considering own historical, national, and cultural experience of reforms in the field of decentralization.

Regionalization, the consolidation of territorial units, the decentralization and reformation of the system of local self-government bodies, the development of inter-municipal cooperation, and the formation of a capable local self-government are the main methods (ways) to exercise the right of states in the field of decentralization $^{3}$. Regionalization is the provision of regions and other territorial state units with the powers in the field of economic development issues of the respective region by concluding agreements on cooperation between territorial communities and power bodies of other states. Local power bodies of the border regions have opportunities to develop special complex programs of economic, cultural, humanitarian interaction, implement specific cross-border economic projects, solve employment problems, as well as infrastructure and environment issues. The European Union encourages cross-border cooperation, in particular through the PHARE program, etc. to assist candidate countries from Central and Eastern Europe in preparation for the EU accession ${ }^{4}$.

The most common way of exercising the right of states in the field of decentralization is the consolidation of territorial units. Since 1950 in Europe, the total number of local self-government units has decreased substantially by almost 40 thousand in total. Thus, Norway has reduced the number of its municipalities by $40 \%$, Germany - by $41 \%$, Sweden $-74 \%$, Denmark $-75 \%$, and the United Kingdom - by $79 \%{ }^{5}$. For the consolidation of municipalities, two main methods are applied such as: stimulation of the voluntary unification of municipalities and the administrative consolidation. There are states that give preference to one of these methods solely, at the same time some of the states use them on alternative basis $^{6}$. Thus, Finland applied a voluntary method of decentralization by granting a subsidy from the state budget. The amount of the subsidy was differentiated - it was increased in cases of: the unification of communes with a population of more than 20 thousand; the implementation of the unification in the first years of reforms; increase in the number of communes

\footnotetext{
${ }^{2}$ Петришина М.О., Петришин О.О. Міжнародно-правові стандарти у сфері місцевого самоврядування. Харків : Право, 2016. С. 10; Свропейська хартія місцевого самоврядування від 15.10.1985 p.

${ }^{3}$ Петришина М.О., Петришин О.О. Міжнародно-правові стандарти у сфері місцевого самоврядування. Харків : Право, 2016. С. 28.

${ }^{4}$ Петришина М.О., Петришин О.О. Міжнародно-правові стандарти у сфері місцевого самоврядування. Харків : Право, 2016. С. 29.

5 Данилишин Б.М., Пилипів В.В. Децентралізація в країнах СС: уроки для України. Регіональна економіка. 2016. № 1. С. 5; Петришина М.О., Петришин О.О. Міжнародно-правові стандарти у сфері місцевого самоврядування. Харків : Право, 2016. С. 29-30.

${ }^{6}$ Петришина М.О., Петришин О.О. Міжнародно-правові стандарти у сфері місцевого самоврядування. Харків : Право, 2016. С. 30.
} 
united. The number of municipalities has decreased from 450 to 320 . The average number of municipalities makes about 17,000 residents, but there is a large amount of communities (almost 50\%) with a population of less than 6,000 people. Today, Finland continues a policy of municipality consolidation as a result of the program "New Municipality 2017" 7 .

In Denmark, the system of local self-government has been strengthened by consolidating the territories and assigning reliable sources of revenue (personal income tax from citizens, land tax, corporate tax, fees and payments, interests, loans, reimbursements and grants) since 2007. The number of communes has decreased from 271 to 98 , and their size has increased significantly - almost $75 \%$ of communities with a population of more than 30 thousand, the average number exceeds 50 thousand people. In addition, the consolidation also involved regions ranging from 14 to 5 with a population of 0.6-1.6 million people, which allowed them to enter a group of regions of the level NUTS-2 and, accordingly, become objects of regional policy of the EU (the EU cohesion policy). In total, 65\% of all budget expenditure is financed from local budgets, while $53 \%$ of budgets are financed from local self-government budgets and only $12 \%$ from regional ones ${ }^{8}$.

Belgium applied an administrative consolidation method. The number of municipalities was reduced from 2359 (1975) to 589 (1988) with the initiative of the Ministry of Internal Affairs in 1975. The unification of communes was carried out based on the following principles: a) each merger was carried out on the basis of a "main commune" which cooperates with others, considering the field of influence and the role it played; b) consideration of factors such as lifestyle of the relevant population groups, and their similarity (Belgium consists of four "linguistic" regions); (c) industrial zones should be grouped under the sole supervision if possible; d) the principle of complementarity providing that new municipalities had to include residential, green, industrial, agricultural and commercial areas necessary for the creation of the most balanced community ${ }^{9}$.

In Latvia, both methods were applied gradually: at the first stage of the reform from 1998 to 2003, according to the Law "On Administrative and Territorial

\footnotetext{
${ }^{7}$ Петришина М.О., Петришин О.О. Міжнародно-правові стандарти у сфері місцевого самоврядування. Харків : Право, 2016. С. 30; Управління стратегічним розвитком об'єднаних територіальних громад: інноваційні підходи та інструменти : монографія / С.М. Серьогін, Ю.П. Шаров, С.І. Бородін, Н.Т. Гончарук [та ін.]; за заг. та наук. ред. С.М. Серьогіна, Ю. П. Шарова. Д.: ДРІДУ НАДУ, 2016. С. 45; Данилишин Б.М., Пилипів В.В. Децентралізація в країнах ЄС: уроки для України. Регіональна економіка. 2016. № 1. С. 6.

${ }^{8}$ Данилишин Б.М., Пилипів В.В. Децентралізація в країнах ЄС: уроки для України. Регіональна економіка. 2016. № 1. С. 6.

${ }^{9}$ Бугай С.М. Жовнірчик Я.Ф. Про напрями вдосконалення територіальної організації місцевого самоврядування. Продуктивні сили України. 2009. № 1. С. 127; Управління стратегічним розвитком об’єднаних територіальних громад: інноваційні підходи та інструменти : монографія / С.М. Серьогін, Ю.П. Шаров, Є.І. Бородін, Н.Т. Гончарук [та ін.]; за заг. та наук. ред. С.М. Серьогіна, Ю.П. Шарова. Дніпро : ДРІДУ НАДУ, 2016. С. 46.
} 
Reform", the voluntary unification of communities was foreseen. During this period, only 26 unified communities were established, representing less than $5 \%{ }^{10}$. The main reason for failure of the reform first stage is the lack of effective mechanisms of stimulation and state support for the transformation from the "bottom". Later on, in accordance with the decisions of the government as of 04.09.2007 and 19.12.2008 on the new administrative division of Latvia, 553 selfgovernments (districts, volosts, etc.) were united in 109 territories (novads) unified communities. After unification, the state gave an additional subsidy in the amount of $1-5 \%$ of the total budget of the unified volosts. For each community created under the project, 285 thousand euros of one-time subsidies was allotted and used, as a rule, for the territorial infrastructure. Since 2009, the second stage of the unification, namely, administrative consolidation of the remaining municipalities taking place without the allocation of inter-budgetary transfers - has begun, and 35 self-governments were united without any subsidies ${ }^{11}$. The financial and legal basis for the existence of local communities is the Law of Latvia "On budgets of self-governments" and "On financial equalization of self-government resources", adopted during 1995-1998. Today, taxes (personal income tax distributed between the state and local budgets, real estate tax, etc.), transfers from the state budget, local taxes, local duties, service fees are main sources of local budget revenue in Latvia. Budget equalization has been in force since 1995, but budget balancing has been used only partially ${ }^{12}$.

Poland has used an administrative method of consolidation. Territories returned to the division that had existed before the Second World War, although today the boundaries can be changed ${ }^{13}$. The reform took place in two stages. From March 1990 to 1998, the legislation on the functioning of a local selfgovernment basic level - gminas (communities) - was adopted. Gminas inherited 50 thousand objects of the former state infrastructure. In 1998, the second stage of the reform began with the introduction of three-level structure of the territorial division of the voivodeship-powiat-gmina. In addition to the consolidation of voivodeships from 49 to 16 , at the same time the power influence of a voivode as an officer of central executive power was reduced. Local communities have received the proper legal status, a large part of local taxes, property that they can dispose independently ${ }^{14}$. Poland is divided into 16 voivodeships (regions), 379 powiaty (counties) and 2478 gminas (communities).

\footnotetext{
10 Нападовська Г.Ю. Міжнародний досвід формування та просторове впорядкування. URL: http://ekhsuir.kspu.edu/bitstream/123456789/3816/1/Napadovskaya_s\%20Гомель.pdf.

11 Чепель О.Д. Децентралізаційні процеси в Україні та Латвії: порівняльне дослідження. Право і суспільство. 2017. № 1. С. 54.

12 Ткачук А.Ф. Латвія: довга дорога реформ. Робочі записки. Київ : Легальний статус. 2015. С. 25.

${ }^{13}$ Польський досвід: спроможність гмін. URL: http://decentralization.gov.ua/news/7060

${ }^{14}$ Cac O. Чи було полякам легко робити децентралізацію. URL: http://decentralization.gov.ua/news/2547.
} 
All these levels are independent of each other financially, and operate on the principles of subsidiarity and guaranteed revenue. Every level fulfills its scope of powers, the closest to the public. So, gminas are responsible for the primary school and medical local roads. Powiaty are responsible for high schools and higher educational institutions, hospitals, roads between cities and villages. And voivodes hips themselves ensure functioning of national higher education institutions, highways of state significance and specialized hospitals ${ }^{15}$. Local budgets account for about $40 \%$ of income taxes, almost $7 \%$ of corporate tax revenue and $100 \%$ of real estate taxes. For budget equalization in Poland, the system of mutual assistance of one region to another one operates under the conditions of surplus and budget deficit ${ }^{16}$.

The consolidation of communities in Lithuania took place based on the Law of the Republic of Lithuania as of 07.06.1994 "On Local Self-Government" (as amended on 12.10.2000 and 15.09.2008). At the same time, the preparation of administrative and territorial division reform was in progress. The criteria for the formation of communities in Lithuania were as follows: the number of residents was not less than 10-12 thousand, including at least 5 thousand in the center of the community, the distance from the center was not more than $20 \mathrm{~km}$, the level of community provision with resources, budget formation (revenue from personal income tax should make not less than 20\%). As a result, 10 districts were created controlled by the central government, and 56 communes municipalities (44 rural and 12 urban), as well as about 450 elderships at submunicipal level (seniunija) which do not have the status of administrativeterritorial units and are subordinated to municipalities ${ }^{17}$.

It should be noted that the territorial basis of local administration is developing not only in the direction of its consolidation by creating larger united territorial units, but also towards the formation of smaller units. This way, in many states the public self-government bodies are formed without their own powers and budgets at the micro level, inside the municipal entities (in particular, parishes in the UK, village councils in German lands, and subcouncils of Bulgaria) ${ }^{18}$.

The mechanisms of inter-municipal cooperation became the only opportunity to execute a wide range of powers locally for the states that had not undergone

15 Корчак I.Я. Польський досвід: як організувати ефективне самоврядування. URL: http://kluchdoprocvitania.blogspot.com/p/blog-page_2.html.

${ }^{16}$ Польський досвід: спроможність гмін. URL: http://decentralization.gov.ua/news/7060; Бугіль С.Я., Степанюк Л.І. Ефективність функціонування місцевих бюджетів в умовах децентралізації публічних фінансів. Молодий вчений. 2018. № 2.

17 Прокопенко Л.Л. Досвід реформування місцевого управління в країнах Європейського Союзу. Аспекти публічного управління. 2015. № 4. С. 99.

18 Петришина М.О., Петришин О.О. Міжнародно-правові стандарти у сфері місцевого самоврядування. Харків : Право, 2016. С. 31-32. 
consolidation at the local level. Inter-municipal cooperation is based on the exercise of the right of local communities (communes) to cooperate in the exercise of their powers, including the entry in association with other local communities (communes) under the law for solving tasks of common interest provided in Article 10 of the European Charter of Local Self-Government. Examples of municipal cooperation include voluntary collaborative work, intermunicipal agreements, redistribution of powers at a sub-national (regional) or national level ${ }^{19}$. The practice of inter-municipal cooperation in France is the most developed one, where the number of inter-municipal units exceeds 2.5 thousand, and their activity involves about $93 \%$ of all communes. Cooperation can be implemented in an easy way - without proper funding, reaching solely the objectives of ensuring the provision of certain joint services, and in the form of establishing an inter-municipal unit with its own financing for the implementation of the powers delegated from the founders -communes ${ }^{20}$. The rules of association and inter-municipal cooperation are contained in the general Code of Territorial Communities and the French Tax Code. As a rule, a representative of the state, namely, a prefect initiates new associations of communes $^{21}$. As a result of the reform in 2010, the amount of local budgets was more than 200 billion euros that was more than half of the state budget. The expenditure of territorial communities and their associations are funded mainly by two types of funds: tax revenue of more than 110 billion euros, including 70 billion euros of direct taxes (housing tax, professional tax, land tax, transport tax, tax on street cleaning, etc.), and financial assistance from the state (interbudgetary transfers) in excess of 57 billion euro ${ }^{22}$.

In Canada, communities collaborate when they cannot solve a local problem themselves, or because they do not want to join more community that is capable. Under the Canadian Constitution, province governments can unite communities if it increases the effectiveness of their activities. Only in the period from 1991 to 2001 the number of municipalities was reduced from 839 to 448 . Cities were joined by suburbs, villages and settlements. In such "mixed" communities, it is rather difficult task to take into account the interests of each subject of the association. In Canada, the consolidation of communities has not become a

\footnotetext{
19 Петришина М.О., Петришин О.О. Міжнародно-правові стандарти у сфері місцевого самоврядування. Харків : Право, 2016. С. 33-34.

20 Данилишин Б.М., Пилипів В.В. Децентралізація в країнах ЄС: уроки для України. Регіональна економіка. 2016. № 1. С. 7.

${ }^{21}$ Марку Жерар. Реформа місцевого самоврядування у Франції як поглиблення міжмуніципального співробітництва. Науковий вісник Академії муніциипального управління. Серія : Право. 2011. Вип. 2. C. $137-139$.

${ }^{22}$ Алєксєєв I.В., Лопушняк Г.С., Ливдар М.С. В. Бюджетний механізм і соціально-економічний розвиток регіонів : Монографія. Львів: Ліга-Прес, 2014. С. 46; Алфьоров С.В. Особливості устрою та функціонування територіальних громад країн-членів СС. Проблеми і перспективи розвитку банківської системи Украӥни. 2013. Вип. 37. С. 186.
} 
universal solution for decentralization problems. The imperfection of a community association mechanism has encouraged municipalities in Canada to consider cooperation as an alternative to unification ${ }^{23}$.

Through the mechanisms of inter-municipal cooperation in Finland, a significant number of services are provided at the local level, namely: at present, there are 162 joint medical centers serving a number of small municipalities, and specialized medicine covers medical districts under the administration of the municipal councils. The "Master's municipality model", as a main model of inter-municipal cooperation, lies in the fact that one municipality executes a range of functions for a group of municipalities or contractual co-operation concerning utility services and education. At the same time, quantitative criteria for population size were determined, in particular, in the healthcare area 20 thousand inhabitants, vocational education -50 thousand inhabitants for the participation in inter-municipal cooperation ${ }^{24}$.

There is yet another method such as decentralization and reform of the system of local self-government bodies - a transfer of the part of state powers to territorial entities ${ }^{25}$. By giving territorial entities new powers, the state provides individuals with the opportunity to participate in solving local issues through their participation in the work of local self-government bodies elected in a democratic way and through other forms of pure democracy. In particular, Spain is an example of so-called regional decentralization, when the main results of decentralization are concentrated in the direction of transferring powers from the central government to the governments of autonomies (regions). At present, autonomy costs account for $35 \%$ of Spanish total public expenditure, while only $13 \%$ of expenditures are financed through municipalities ${ }^{26}$.

Sweden chose the way of the capable self-government formation - most of the functions of the social state are executed at the level of communes or län (counties). The correlation of utility expenditures and costs of counties makes 70 to 30. In 2005 in Sweden the sub, sidy mechanism was changed. State allocations are calculated in order to reduce the difference in tax basis between different municipalities per 1 resident $^{27}$.

\footnotetext{
23 Объединение общин или межмуниципальное сотрудничество: Опыт Канады для Украины. Украӥнська правда. URL: https://www.pravda.com.ua/rus/columns/2017/07/5/7148494/

24 Данилишин Б.М., Пилипів В.В. Децентралізація в країнах ЄС: уроки для України. Регіональна економіка. 2016. № 1. С. 7.

25 Петришина М.О., Петришин О.О. Міжнародно-правові стандарти у сфері місцевого самоврядування. Харків : Право, 2016. С. 32.

26 Данилишин Б.М., Пилипів В.В. Децентралізація в країнах ЄС: уроки для України. Регіональна економіка. 2016. № 1. С. 7-8.

27 Петришина М.О., Петришин О.О. Міжнародно-правові стандарти у сфері місцевого самоврядування. Харків : Право, 2016. С. 34.
} 
It is worth noting that regions in the EU (including municipalities or communes) are not only the subject of state or regional policy, but also "The EU cohesion policy" that accounts for one third of the community budget. In most cases, the least developed regions are recipients of assistance. So, when assessing the experience of implementing decentralization reforms in such states, this fact should be taken into account. Thus, Polish communities and regions have been able to use large amount of resources for development purposes, and since 2011 they have become leaders in the amount of funds from EUR 14.44 billion in 2011 to EUR 17.436 billion in 2014 allotted from the EU budget. The European Regional Development Fund (ERDF) is a key instrument of the EU regional policy and it allocates almost $60 \%$ of all funds intended for regional development, while co-funding is provided from local budgets ${ }^{28}$.

\section{Financial and Legal Aspects of Power Decentralization in Ukraine}

In 2014 the reforms in the field of decentralization of power aimed at the formation of a three-level administrative system began in Ukraine: 1) basic level - communities, 2) district level - districts and 3) regional level - the Autonomous Republic of Crimea, regions, cities Kiev and Sevastopol ${ }^{29}$. The basic level of the administrative-territorial system is represented by village, settlement and city councils, as well as councils of the united territorial communities (hereinafter UTCs), created in accordance with the legislation and a long-term plan for the formation of community territories. The reform mentioned is carried out by differentiating powers in the system of local selfgovernment bodies and executive power bodies at different levels of administrative-territorial entities on the principle of subsidiarity, creation of proper material, financial and organizational conditions for ensuring the exercise of powers by local self-government bodies, etc. Thus, Ukraine has chosen such method of decentralization as consolidation at the basic level.

Village, settlement and city councils started the process of unification when the Law of Ukraine "On Voluntary Unification of Territorial Communities" (here in after - the Law) had come into force ${ }^{30}$. Such unification is conducted around potential administrative centers determined according to the methodology established by the Government of Ukraine ${ }^{31}$. In 2017, the adjacent village and settlement territorial communities of regions, belonging to such UTC

\footnotetext{
28 Данилишин Б.М., Пилипів В.В. Децентралізація в країнах СС: уроки для України. Регіональна економіка. 2016. № 1. С. 9.

${ }^{29}$ Про схвалення Концепції реформування місцевого самоврядування та територіальної організації влади в Україні: Розпорядження Кабінету Міністрів України від 01.04.2014 р. № 333-р. Урядовий кур'єр. 2014. № 67.

${ }^{30}$ Про добровільне об’єднання територіальних громад: Закон України від 05.02.2015 р. № 157-VIII. URL: https://zakon.rada.gov.ua/laws/show/157-19.

31 Про затвердження Методики формування спроможних територіальних громад: Постанова Кабінету Міністрів від 08.04.2015 р. № 214. Офіиійний вісник України. 2015. № 33. Ст. 963.
} 
under the long-term plan for forming the territories of the Autonomous Republic of Crimea, acquired the right to voluntarily adhesion to a capable UTC. At the same time, territorial communities of the cities of the republican significance of Autonomous Republic of Crimea and region significance acquired the status of capable territorial communities; therefore, other territorial communities have acquired the right to join them only since $05.05 .2018^{32}$. Village, settlement and city councils have the right only to voluntarily enter into legal relation regarding the formation and adherence to capable UTCs as subjects of financial decentralization, but this voluntariness is limited by the imperativeness of state orders, as well as there is no equality of the parties in this relation. If UTC council makes a decision to refuse to give consent to voluntarily adhesion of another territorial community with its consent, the Government may revoke the decision to recognize such UTC as capable. Consequently, UTC will not be considered such in terms of the legal norms of the Budget Code of Ukraine (hereinafter - the BC of Ukraine) $)^{33}$. Among 665 UTCs created during 2015-2017, 654 UTCs were recognized as capable.

The issues of decentralization by consolidation do not become irrelevant, since 6934 local councils do not participate in the process of decentralization today; that is $63.3 \%$ of the total number of basic level councils for $2015^{34}$. In the fifth year of the reform, one of regions still cannot submit and approve a longterm plan. Most of the regions have community development plans far from covering the whole their territory ${ }^{35}$. In 2015-2019 4018 territorial communities united in 876 UTCs $(36.7 \%$ of the total number of basic level councils as of 01.01.2015), of which 72 are waiting for a decision on the appointment of the first election (including 45 UTCs, in which elections did not take place due to the introduction of martial law, and 24 cities of region significance joined by 59 territorial communities). In 97 districts (not taking into account 25 districts of the occupied territories of the Autonomous Republic of Crimea, Donetsk and Luhansk regions) UTCs have not been formed ${ }^{36}$. There are also many communities united not by the requirements of long-term plans. They believe

\footnotetext{
${ }^{32}$ Про добровільне об’єднання територіальних громад: Закон України від 05.02.2015 р. № 157-VIII. URL: https://zakon.rada.gov.ua/laws/show/157-19.

${ }^{33}$ Бюджетний кодекс України, 08.07.2010 p. № 2456-VI. URL: http://zakon2.rada.gov.ua/laws/show/245617 п. 2-1 ст. 2

${ }^{34}$ Міністерство регіонального розвитку, будівництва та житлово-комунального господарства України Моніторинг процесу децентралізації влади та реформування місцевого самоврядування станом на 10 лютого 2019 p. (за січень 2018): національний проект децентралізація. URL: https://storage.decentralization.gov.ua/uploads/library/file/378/10.02.2019_ukr_.pdf.

35600 днів до нового адміністративно-територіального устрою країни: що за цей час треба зробити коментар В'ячеслава Негоди. URL: decentralization.gov.ua/news/9950.

${ }^{36}$ Міністерство регіонального розвитку, будівництва та житлово-комунального господарства України Моніторинг процесу децентралізації влади та реформування місцевого самоврядування станом на 10 лютого 2019 p. (за січень 2018): національний проект децентралізація. URL: https://storage.decentralization.gov.ua/uploads/library/file/378/10.02.2019_ukr_.pdf.
} 
that they will be able to provide and develop their community independently, even without any government support ${ }^{37}$.

Describing UTC's powers, in addition to Art. 142 of the Constitution of Ukraine, one should pay attention to Part 2 of Art. 19 of the Basic Law - bodies of local self-government, their officials are obliged to act only on the basis, within the limits of powers and in the manner stipulated by the Constitution and laws of Ukraine ${ }^{38}$. There is no direct legal norm for the provision of UTCs, created in accordance with the law and a long-term plan for the formation of community territories within the budget legal relation, with powers at the level of cities of region significance without the status of a capable UTC and the official status of a city of region significance ${ }^{39}$. In the legal definition as well as in the concept of "local borrowing" (Article 33, Part 1, Article 2 of the BC of Ukraine) and Articles 16, 17 and 74 of the Budget Code of Ukraine, which define the mechanism for exercising the right of local councils to local borrowings and guarantees, UTCs as entities in such relationship are not mentioned. Thus, UTCs do not belong to the subjects of local borrowing and guarantees. So, it should be noted at once that such right has been granted to regional councils since $01.01 .2019^{40}$.

The state carries out financial support for voluntary unification, territorial adhesion of communes of villages, settlements, and cities ${ }^{41}$. UTCs are subjects of financial relation in the field of inter-budgetary transfers: they have the right to obtain basic, additional and stabilization subsidies, subventions ${ }^{42}$. In addition, UTCs are the subjects of relation in the field of reverse subsidies - they are the funds transferred to the state budget from local budgets for horizontal equalization of taxable capacity of territories ${ }^{43}$. An additional subsidy is provided for compensation of losses of local budget revenue due to the provision of benefits established by the state, as well as for transfer of expenditures from the State budget for maintenance of educational and health facilities. A stabilization subsidy is temporary and is provided to: budgets of cities of region significance, local budgets and budgets of UTCs, in which the index of relative taxable capacity is less than similar average value in such budgets; regional budgets - for distribution between local budgets in the manner determined by regional state administrations. In 2018 stabilization subsidy from State budget to

\footnotetext{
37 Проблеми децентралізації, або як відбувається об'єднання громад на Донеччині: URL: http://decentralization.gov.ua/news/5221?page $=5$.

${ }^{38}$ Конституція України від 28.06.1996 № 245к/96-ВР. Відомості Верховної Ради Украӥни. 1996. № 30. CT. 141.

39 Сударенко О.В. Об'єднані територіальні громади як суб'єкти фінансового права. Право і суспільство. 2017. № 4. С. 120.

${ }^{40}$ Бюджетний кодекс України. Абз. 2 ч. 3 ст. 16, ч. 2 ст. 17.

${ }^{41}$ Про добровільне об’єднання територіальних громад: Закон України. Ч. 1, ст. 10.

42 Сударенко О.В., Петриченко М.О. Правове регулювання міжбюджетних трансфертів. Право і суспільство. 2018. № 5. С. 166-167.

${ }^{43}$ Бюджетний кодекс України. ст. 96
} 
local budgets was allotted in the amount of 200,000 thousand $\mathrm{UAH}^{44}$. A subvention is no less important inter-budgetary transfer. If, in 2014, a subvention was allocated to UTC in the amount of 0.5 billion UAH only for socio-economic development of territories, after that in 2018, in addition to the subvention mentioned (5.0 billion UAH), another amount of 6.0 billion UAH funds from the State Fund for Regional Development, 1.9 billion UAH - funds for the development of UTC infrastructure, 0.37 billion UAH for construction of football fields, 5.0 billion UAH - funds for the development of medicine in rural areas and 1.1 billion UAH - funds in support of sectoral regional policy were allocated. At the same time, on 10.10 .2018 only 2.1143 billion UAH was distributed by the Government of Ukraine from specified 5 billion UAH subvention for social development ${ }^{45}$. In 2019, a new subvention for financial support for the construction, reconstruction, repair and maintenance of public roads of local importance, streets and roads of communal property in settlements is envisaged ${ }^{46}$.

The sources of the local budget formation in Ukraine are personal income tax (60\% of which remains in the budgets of UTCs), excise and local taxes, license fees, administrative fees, etc. The share of local taxes and fees in local government revenue increased from $0.7 \%$ (2014) to $30 \%$ (2018). Out of 930 cities of region significance and UTCs, 100 UTCs, including 12 UTCs, received architectural and building control powers; 646 UTCs received 1450.8 thousand hectares of agricultural land in communal ownership. As a result of the decentralization reform, the income per one resident increased in the UTC. In 2019 , in comparison with 2014, support for local and regional development has increased by 41.5 times $^{47}$.

Ukraine draws much attention to improvement of processes of inter-municipal cooperation. The legal basis for community cooperation in Ukraine is the Law of Ukraine "On Cooperation of Territorial Communities" place in the field of collection and recycling of waste, provision of quality centralized water supply and drainage, repair and cleaning of roads, organization of passenger transportation, maintenance of fire protection, provision of

\footnotetext{
44 Про Державний бюджет України на 2018 рік: Закон України від 07.12.2017 № 2246-VIII. Голос України. 2017. № 249-250. ст. 3, додаток № 7.

${ }^{45}$ Міністерство регіонального розвитку, будівництва та житлово-комунального господарства України Моніторинг процесу децентралізації влади та реформування місцевого самоврядування (жовтень 2018). URL: storage.decentralization.gov.ua/uploads/library/file/318/10.10.2018.pdf.

${ }^{46}$ Бюджетний кодекс України. Ст. 103-1.

${ }^{47}$ Міністерство регіонального розвитку, будівництва та житлово-комунального господарства України Моніторинг процесу децентралізації влади та реформування місцевого самоврядування станом на 10 лютого 2019 p. (за січень 2018): національний проект децентралізація. URL: https://storage.decentralization.gov.ua/uploads/library/file/378/10.02.2019__ukr_.pdf

${ }^{48}$ Про співробітництво територіальних громад: Закон України від 17.06.2014 р. № 1508-VIII. Голос України. 2014. № 138.
} 
administrative services. As of 13.02.2019, 1300 territorial communities concluded 339 agreements of inter-municipal cooperation ${ }^{49}$.

The method of regionalization is widely used through the signing of the trilateral memoranda: the development agency of the UTC of Prykarpattya on cooperation with the leadership of the Joint Technical Secretariat of the Romania-Ukraine Program 2014-2020 and the Executive Directorate of the regional office of cross-border cooperation in Suchava city (establishing communication with the Romanians on issues of writing and implementation of joint projects); Ivano-Frankivsk Regional State Administration, regional council and the program of the United States Agency for International Development (USAID) "Decentralization brings better results and effectiveness (DOBRE)"; 14.12.2018 Demydiv UTC in Rivne region joined the European initiative of "Covenant of Mayors" (the initiative launched by the EU to develop a green economy, to reduce $\mathrm{CO}_{2}$ emissions and widely implement energy efficient projects and measures $)^{50}$. In addition, cooperation takes place at the level of executive power bodies of our state. Thus, the Ministry of Regional Development, Construction and Housing and Communal Services of Ukraine, the Embassy of the Republic of Lithuania in Ukraine and Agriteam Canada Consulting LTD signed a memorandum, according to which Regional project management centers will be established ${ }^{51}$.

In 2020, the second stage of the decentralization reform in Ukraine will begin - administrative consolidation of those UTCs that have not participated in the voluntary unification. Moreover, the state plans to approve a new territorial basis of Ukraine - 100 capable districts and 1600-1800 capable communities, to consolidate financial self-sufficiency of local self-government, and form an effective management system ${ }^{52}$.

\section{CONCLUSIONS}

International experience of exercise of the state right in the field of decentralization proves positive aspects in the area of power division in the system of self-government bodies and executive power bodies at the different levels of administrative and territorial entities based on the principle of subsidiarity, creation of proper material, financial and organizational conditions

\footnotetext{
${ }^{49}$ Міністерство регіонального розвитку, будівництва та житлово-комунального господарства України Реєстр договорів про співробітництво територіальних громад. URL: https://www.minregion.gov.ua/wpcontent/uploads/2019/02/reestr-13.02.2019.pdf

50 Прикарпатські ОТГ спільно 3 європейськими партнерами реалізовуватимуть транскордонні проекти. URL: https://decentralization.gov.ua/news/10605; Допомога проекту «DOBRE» дає змогу прикарпатським громадам успішно розвиватися. URL: https://decentralization.gov.ua/news/10589; ОTГ на Рівненщині приєдналися до Свропейської «Угоди мерів». URL: https://decentralization.gov.ua/news/10416.

51 За підтримки Канади та Литви в Україні створять Регіональні центри проектного менеджменту. URL: https://decentralization.gov.ua/news/10633

${ }^{52}$ Коваль Л. Перший етап децентралізації завершено. Урядовий кур 'єр. 2019. № 15.
} 
to ensure execution of powers by self-government bodies etc. The methods of exercise of the state right in the field of decentralization include regionalization, voluntary and administrative consolidation of administrative territorial entities, reformation of self-government bodies, inter-municipal cooperation development and formation of capable local self-government. The states achieve the most positive outcomes by uniting several methods of decentralization. The reforms are characterized by the provision of inter-budgetary transfers from the state, consolidation of reliable sources of revenue from local budgets, creation of a "master's municipality model", conclusion of inter-municipal agreements, cross-border cooperation, and voluntary collaborative work.

Ukraine has chosen such method of decentralization as consolidation of territorial units at the basic level: voluntary decentralization with the consolidation of reliable sources of revenue for UTCs and through allocation of inter-budgetary transfers from 2015 to 2019, and administrative consolidation from 2020. Today, UTCs are beginning to use other methods of decentralization widely. At the same time, there are many communities, united not by the requirements of long-term plans, maintaining and developing their community independently, even without the governmental support. A mechanism should be provided for the exercise of the community right to unite despite the requirements of a long-term plan and without application of administrative consolidation to them, if such unification is financially justified. In order to ensure consistency in decision-making by the state bodies of Ukraine, in determining the competence of the UTC and capable UTC, appropriate changes to the legislation should be made.

\section{SUMMARY}

The article deals with the research of financial and legal aspects of power decentralization reform both in countries worldwide and in Ukraine. The practice in the application of methods on exercise of the state right in the field of decentralization is examined. It is determined that positive outcomes of the reforms are characterized by uniting several methods of decentralization, providing inter-budgetary transfers from the state, assigning reliable sources of revenue to local budgets, creating a "master's municipality model", intermunicipal agreement conclusion, cross-border cooperation, and voluntary collaborative work. In the EU countries, "The EU cohesion policy" is also applied. Considering international experience of power decentralization reform gave an opportunity to Ukraine to curtail the time for the reform implementation as well as avoid some other problems that other states faced. In Ukraine, the first stage of the reform is coming to an end, namely, voluntary consolidation of territorial units; administrative consolidation will be applied in 2020. It is emphasized that the rights of communities for unification must be taken into 
account despite of the prospective plan if such unification is justified in terms of funding and administrative consolidation must not be applied to them. The proposals for legislation improvement in the field of decentralization mentioned are made.

\section{REFERENCES}

1. Барановська Т.М. Державна політика розвитку територіальних громад в Україні: дис. ... канд. наук з державного управління. Харків, 2016. 261 с. URL: http://www.kbuapa.kharkov.ua/dorad/files/btm_dis_20170306.pdf

2. Петришина М.О., Петришин О.О. Міжнародно-правові стандарти у сфері місцевого самоврядування. Харків : Право, 2016. 44 с.

3. Свропейська хартія місцевого самоврядування від 15.10.1985 p. URL: https://zakon.rada.gov.ua/laws/show/994_036.

4. Управління стратегічним розвитком об’єднаних територіальних громад: інноваційні підходи та інструменти : монографія / С.М. Серьогін, Ю.П. Шаров, С.І. Бородін, Н.Т. Гончарук [та ін.]; за заг. та наук. ред. С.М. Серьогіна, Ю.П. Шарова. Дніпро : ДРІДУ НАДУ, 2016. 276 с.

5. Данилишин Б.М., Пилипів В.В. Децентралізація в країнах СС: уроки для України. Регіональна економіка. 2016. № 1. C. 5-11. URL: http://irg.gov.ua/pe/re201601_005_DanylyshynBM,PylypivVV.pdf

6. Бугай С.М., Жовнірчик Я.Ф. Про напрями вдосконалення територіальної організації місцевого самоврядування. Продуктивні сили України. 2009. № 1. С. 126-134.

7. Нападовська Г.Ю. Міжнародний досвід формування та просторове впорядкування. URL: http://ekhsuir.kspu.edu/bitstream/123456789/3816/1/ Napadovskaya_s\%20Гомель.pdf.

8. Чепель О.Д. Децентралізаційні процеси в Україні та Латвії: порівняльне дослідження. Право і суспільство. 2017. № 1. С. 52-56.

9. Ткачук А.Ф. Латвія: довга дорога реформ. Робочі записки. Київ : Легальний статус. 2015.56 с.

10. Польський досвід: спроможність гмін. Офіційний сайт щодо децентралізації влади. URL: http://decentralization.gov.ua/news/7060.

11. Сас О. Чи було полякам легко робити децентралізацію. Офіційний сайт щодо децентралізації влади. URL: http://decentralization.gov.ua/ news/2547.

12. Корчак I.Я. Польський досвід: як організувати ефективне самоврядування. URL: http://kluchdoprocvitania.blogspot.com/p/blogpage_2.html.

13. Бугіль С.Я., Степанюк Л.І. Ефективність функціонування місцевих бюджетів в умовах децентралізації публічних фінансів. Молодий вчений. 2018. № 2. URL: http://molodyvcheny.in.ua/files/journal/2018/2/87.pdf. 
14. Прокопенко Л.Л. Досвід реформування місцевого управління в країнах Європейського Союзу. Аспекти публічного управління. 2015. № 4. C. 93-101.

15. Марку Жерар. Реформа місцевого самоврядування у Франції як поглиблення міжмуніципального співробітництва. Науковий вісник Академії муніципального управління. Серія : Право. 2011. Вип. 2. C. $136-145$.

16. Алєксєєв І.В., Лопушняк Г.С., Ливдар М.С. В. Бюджетний механізм і соціально-економічний розвиток регіонів : Монографія. Львів : Ліга-Прес, 2014. 248 c.

17. Алфьоров С.В. Особливості устрою та функціонування територіальних громад країн-членів СС. Проблеми і перспективи розвитку банківської системи Украӥни. 2013. Вип. 37. С. 181-189.

18. Объединение общин или межмуниципальное сотрудничество: Опыт Канады для Украины. Українська правда. URL: https://www.pravda.com.ua/rus/columns/2017/07/5/7148494/

19. Про схвалення Концепції реформування місцевого самоврядування та територіальної організації влади в Україні : Розпорядження Кабінету Міністрів України від 01.04.2014 р. № 333-р. Урядовий кур 'єр. 2014. № 67.

20. Про добровільне об'єднання територіальних громад: Закон України від 05.02.2015 p. № 157-VIII. URL: https://zakon.rada.gov.ua/laws/show/157-19.

21. Про затвердження Методики формування спроможних територіальних громад: Постанова Кабінету Міністрів від 08.04.2015 р. № 214. Офіиійний вісник Украӥни. 2015. № 33. Ст. 963.

22. Бюджетний кодекс України, 08.07.2010 p. № 2456-VI. URL: http://zakon2.rada.gov.ua/laws/show/2456-17.

23. Міністерство регіонального розвитку, будівництва та житловокомунального господарства України Моніторинг процесу децентралізації влади та реформування місцевого самоврядування станом на 10 лютого 2019 р. (за січень 2018): національний проект «Децентралізація». URL: https://storage.decentralization.gov.ua/uploads/library/file/378/10.02.2019 ukr_.pdf.

24. 600 днів до нового адміністративно-територіального устрою країни: що за цей час треба зробити - коментар В'ячеслава Негоди. URL: decentralization.gov.ua/news/9950.

25. Проблеми децентралізації, або як відбувається об'єднання громад на Донеччині: URL: http://decentralization.gov.ua/news/5221?page $=5$.

26. Сударенко О.В. Об'єднані територіальні громади як суб'єкти фінансового права. Право і суспільство. 2017. № 4. С. 118-123.

27. Конституція України від 28.06.1996 р. № 245к/96-ВР. Відомості Верховної Ради Украӥни. 1996. № 30. Ст. 141. 
28. Сударенко О.В., Петриченко М.О. Правове регулювання міжбюджетних трансфертів. Право і суспільство. 2018. № 5. С. 164-165.

29. Про внесення змін до постанови Кабінету Міністрів України від 16 вересня 2015 р. № 727 : Постанова Кабінету Міністрів України від 15.11.2017 p. № 873. URL: http://zakon0.rada.gov.ua/laws/show/873-2017$\% \mathrm{D} 0 \% \mathrm{BF}$.

30. Про Державний бюджет України на 2018 рік: Закон України від 07.12.2017 p. № 2246-VIII. Голос Украӥни. 2017. № 249-250.

31. Міністерство регіонального розвитку, будівництва та житловокомунального господарства України Моніторинг процесу децентралізації влади та реформування місцевого самоврядування (жовтень 2018). URL: storage.decentralization.gov.ua/uploads/library/file/318/10.10.2018.pdf.

32. Про співробітництво територіальних громад : Закон України від 17.06.2014 p. № 1508-VIII. Голос України. 2014. № 138.

33. Міністерство регіонального розвитку, будівництва та житловокомунального господарства України. Реєстр договорів про співробітництво територіальних громад. URL: https://www.minregion.gov.ua/wpcontent/uploads/2019/02/reestr-13.02.2019.pdf.

34. Прикарпатські ОТГ спільно 3 європейськими партнерами реалізовуватимуть транскордонні проекти. URL: https://decentralization.gov.ua/news/10605.

35. Допомога проекту «DOBRE» дає змогу прикарпатським громадам успішно розвиватися. URL: https://decentralization.gov.ua/news/10589.

36. ОТГ на Рівненщині приєдналися до Свропейської «Угоди мерів». URL: https://decentralization.gov.ua/news/10416.

37. За підтримки Канади та Литви в Україні створять Регіональні центри проектного менеджменту. URL: https://decentralization.gov.ua/news/10633.

38. Коваль Л. Перший етап децентралізації завершено. Урядовий кур'єр. 2019. № 15 .

Information about author: Sudarenko O. V.,

Candidate of Judicial Science, Assistant Professor, Assistant Professor of Administrative, Financial and Informational Law Department of Kyiv National University of Trade and Economics 19, Kyoto str., Kyiv, Ukraine 